\title{
PHYLOGENETIC ANALYSIS OF Arcobacter butzleri AND Arcobacter skirrowii ISOLATES AND THEIR DETECTION FROM CONTAMINATED VEGETABLES BY MULTIPLEX PCR
} \author{
$\mathrm{YS}^{5}$, Dhama $\mathrm{K}^{6}$, Singh $\mathrm{RK}^{7}$

\footnotetext{
${ }^{1}$ Division of Veterinary Public Health, ICAR-Indian Veterinary Research Institute, Izatnagar, Bareilly (U.P.)

${ }^{2}$ Indian Council of Agricultural Research Krishi Bhavan, New Delhi-110001

${ }^{3}$ Division of Bacteriology \& Mycology, ICAR-Indian Veterinary Research Institute, Izatnagar, Bareilly (U.P.)

${ }^{4}$ Animal Biotechnology Division, ICAR-Indian Veterinary Research Institute, Izatnagar, Bareilly (U.P.)

${ }^{5}$ Division of Biological Standardization, ICAR-Indian Veterinary Research Institute, Izatnagar, Bareilly (U.P.)

${ }^{6}$ Division of Pathology, ICAR-Indian Veterinary Research Institute, Izatnagar, Bareilly (U.P.) - 243122, India

${ }^{7}$ ICAR-Indian Veterinary Research Institute, Izatnagar, Bareilly (U.P.) - 243122, India
}

Ramees $\mathrm{TP}^{1^{*}}$, Rathore $\mathrm{RS}^{1}$, Kumar $\mathrm{A}^{2}$, Arun $\mathrm{TR}^{3}$, Ravi Kumar GVPPS ${ }^{4}$, Karthik $\mathrm{K}^{3}$, Malik

Received - January 28, 2018; Revision - March 10, 2018; Accepted - April 04, 2018

Available Online - April 25, 2018

DOI: http://dx.doi.org/10.18006/2018.6(2).307.314

KEYWORDS
Arcobacter
vegetables
Contamination
Detection
Multiplex PCR
Phylogenetic analysis

* Corresponding author

E-mail: rameesvet@gmail.com (Dr. Ramees T P)

Peer review under responsibility of Journal of Experimental Biology and Agricultural Sciences.

Production and Hosting by Horizon Publisher India [HPI] (http://www.horizonpublisherindia.in/).

All rights reserved.

\begin{abstract}
Arcobacter is an identified emerging food-borne bacterial pathogen. In the current study, 204 different vegetable samples were collected from retail shops or local vendors from northern part (Uttar Pradesh) of India and screened for Arcobacter spp. The samples were enriched in Arcobacter enrichment broth followed by multiplex PCR based detection of the Arcobacter species. Arcobacter butzleri and Arcobacter skirrowii were detected in $13.73 \%$ (28/204); 23 were positive for A. butzleri, while 5 showed mixed contamination of A. butzleri and A. skirrowii. The specific PCR amplicons from positive samples were purified and sequenced for further analysis. Sequence analysis of Arcobacter spp. showed a significant genetic similarity irrespective of country and source of origin. A. skirrowii isolation is reported for the first time from a vegetable source. The higher incidences of enteric infections in human in resource poor settings, particularly developing countries, could be due to high frequency of Arcobacter contaminations in vegetables. Further epidemiological studies are warranted to probe the role of vegetable contamination in transmission of this important pathogen of global public health concern.
\end{abstract}

All the article published by Journal of Experimental Biology and Agricultural Sciences is licensed under a Creative Commons Attribution-NonCommercial 4.0 International License Based on a work at www.jebas.org.

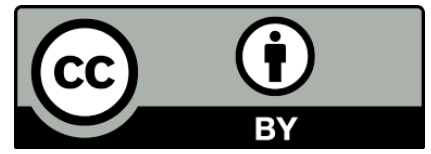




\section{Introduction}

The raw fruits and vegetables have been known to serve as vehicles of various food-borne infections throughout the world and are more frequently noted in developing countries (Greene et al., 2008; Berger et al., 2010; Ferreira et al., 2015). Poor quality water irrigation system is one of the major factors behind contamination of vegetables at the pre-harvest step with foodborne pathogens. A number of outbreaks of human gastroenteritis have been reported by the intake of contaminated fresh vegetables and fruits (Gonzalez \& Ferrus, 2011; Lee \& Choi, 2013; Ferreira et al., 2015). Enterohemorrhagic Escherichia coli, Salmonella, Shigella flexneri, Bacillus cereus, Aeromonas hydrophila and Aeromonas sobria have been isolated from various vegetable sources (Beuchet, 1996; Franz \& van Bruggen, 2008; Park et al., 2012). In one of our previous study, we isolated Campylobacter jejuni from fresh vegetables collected from local market in Bareilly, Uttar Pradesh state of India (Kumar et al., 2001).

Arcobacter is a Gram-negative organism, categorized under the Campylobacteraceae family. Arcobacters have been detected from animal-origin foods such as chicken meat, pork, sea foods, beef and milk (Rivas et al., 2004; Patyal et al., 2011; Dhama et al., 2013; Ramees et al., 2014a; Ramees et al., 2014b). For specific detection of $C$. jejuni and A. butzleri in food products, multiplex PCR assay (mPCR) was suggested by Winters \& Slavik (2000). Using a variable $16 \mathrm{~S}$ rRNA and $23 \mathrm{~S}$ rRNA region, Houf et al. (2000) established a species-specific multiplex PCR assay for the concurrent detection and identification of three important Arcobacter spp. (A. butzleri, A. skirrowii and A. cryaerophilus). Gonzalez et al. (2000) developed a newer method of PCR-culture technique for the quick detection of Arcobacter spp. in chicken meat after a short selective enrichment of samples. Gonzalez et al. (2010) developed a real-time PCR for the detection of Arcobacter spp. in fresh lettuce samples, where A. butzleri being the only species detected by mPCR. Lately, the presences of Arcobacter strains have been shown in a carrot-processing plant (Hausdorf et al., 2011) from lettuce (González \& Ferrús, 2011). A. butzleri was isolated from water body in Germany, a drinking water pool (Jacob et al., 1998) and in the USA from well-water (Rice et al., 1999), signifying that $A$. butzleri can survive in water sources and may even spread through drinking water (Ramees et al., 2017).

Numerous methods are in use for the differentiation of Arcobacter strains including RAPD-PCR, ERIC-PCR, AFLP and PFGE (Hume et al., 2001; Houf et al., 2002; On et al., 2003). Among available detection methods, ERIC-PCR and RAPD-PCR are the more commonly used techniques employed on A. butzleri, A. cryaerophilus, and A. skirrowii isolates forsatisfactory typing. Various other nucleic acid-based methods have been used for detection, identification and monitoring of Arcobacters in food including PCR-plus-RFLP (Neubauer et al., 2003), PCR-plus-
RAPD (Atabay et al., 2002; Houf et al., 2002), and PCR-plus DNA sequencing (Karenlampi et al., 2004). The $16 S$ rRNA sequencing is more accurate which also indicates similarity of Arcobacter and the Epsilon proteobacteria genus (Gilbert et al., 2014).

It is assumed that Arcobacter contamination could be very common in fresh vegetables, as seen in meat samples. Perusal of literature reveals availability of limited knowledge on the detection of Arcobacter from vegetable sources and molecular characterization of the isolates. Hence, we investigated the Arcobacter contamination in fresh vegetable sources collected from retail shops in northern part of India. Subsequently these isolates were subjected to sequence analysis.

\section{Materials and Methods}

\subsection{Collection and processing of samples}

Total 204 fresh vegetable samples were collected from different retail shops of the Bareilly region, Uttar Pradesh, India, comprising of carrot (48), beet root (46), cabbage (38), tomato (29), coriander (21) and cucumber (22) (Table 1). From all the vegetables, $2 \mathrm{~g}$ of the samples or surface scrapings were put in 10 $\mathrm{ml}$ phosphate buffered saline (PBS, $\mathrm{pH}$ 7.2). One $\mathrm{ml}$ of these samples were inoculated in to $9 \mathrm{ml}$ Arcobacter enrichment broth with 7\% sheep blood and CAT (Cefoperazone, Amphotericin B, Teicoplanin) selective supplement and further these were incubated at $30^{\circ} \mathrm{C}$ for $48 \mathrm{hrs}$ micro-aerobically. An amount of 2 $\mathrm{ml}$ of each enriched sample was centrifuged at $10,000 \mathrm{rpm}$ for 15 min for pelleting and genomic DNA was extracted using CTAB method (Wilson, 1987). For the isolation purpose, all the 204 enriched samples were individually filtered through $0.45 \mu \mathrm{m}$ pore size syringe filter on to the Arcobacter blood agar plates containing $7 \%$ blood and kept at $30^{\circ} \mathrm{C}$ for $48-72$ hrs under microaerobic environment (Ramees et al., 2014b). Cultural plates

Table 1 Detection of Arcobacter species by multiplex PCR from vegetable samples

\begin{tabular}{|ccccccc|}
\hline $\begin{array}{c}\text { Sl } \\
\text { No. }\end{array}$ & $\begin{array}{c}\text { Type of } \\
\text { Samples }\end{array}$ & $\begin{array}{c}\text { No. of } \\
\text { samples }\end{array}$ & $\begin{array}{c}\text { Samples detected Positive for Arcobacter spp. } \\
\text { A. butzleri }\end{array}$ & $\begin{array}{c}\text { A. butzleri } \\
\text { And A. } \\
\text { skirrowii }\end{array}$ & Total Percentage \\
\hline 1 & Carrot & 48 & 11 & 3 & 14 & 29.17 \\
\hline 2 & Beet root & 46 & 8 & 2 & 10 & 21.74 \\
\hline 3 & Cabbage & 38 & 4 & 0 & 4 & 10.53 \\
\hline 4 & Tomato & 29 & 0 & 0 & 0 & 0 \\
\hline 5 & Coriander & 21 & 0 & 0 & 0 & 0 \\
\hline 6 & Cucumber & 22 & 0 & 0 & 0 & 0 \\
\hline Total & & 204 & 23 & 5 & 28 & 13.73 \\
\hline
\end{tabular}


showing characteristic morphology of Arcobacter were confirmed by biochemical testing and multiplex PCR.

\subsection{Multiplex PCR for detection of Arcobacter spp.}

The optimized multiplex PCR (mPCR) assay was used to screen all the 204 vegetable samples and simultaneous detection of $A$. butzleri, A. cryaerophilus, and A. skirrowii. The published primer pairs (BUTZ, ARCO, SKIR, CRY-1, and CRY-2) from 16S rRNA and 23S rRNA genes were used in the study (Houf et al., 2000; Patyal et al., 2011). For the positive DNA control, A. butzleri (LMG $10828^{\mathrm{T}}$ ) was used. The PCR reaction was carried out in $25 \mu 1$ reaction buffer taking $2.5 \mu 1$ of 10X PCR buffer; 1 IU of Taq DNA polymerase; $0.2 \mathrm{mM}$ of each deoxyribonucleotide triphosphate (dNTPs), $2.5 \mathrm{mM} \mathrm{MgCl} 2,15$ pmol of the primers ARCO, BUTZ, CRY-1, CRY-2 and 7.5 pmol of primer SKIR; 2 $\mu 1$ of template DNA and to make the final volume nuclease free water was added. . The multiplex PCR cycles involved the single first step of initial denaturation at $94^{\circ} \mathrm{C}$ for $5 \mathrm{~min}$, subsequently 30 thermal cycles of denaturation $\left(94^{\circ} \mathrm{C}\right.$ for $30 \mathrm{sec}$.), primer annealing $\left(51^{\circ} \mathrm{C}\right.$ for $\left.30 \mathrm{sec}\right)$ and chain extension $\left(72^{\circ} \mathrm{C}\right.$ for 1.00 $\mathrm{min}$ ), and single step of final stage extension at $72^{\circ} \mathrm{C}$ for $10 \mathrm{~min}$. On completion of PCR cycles, amplification was observed by running the PCR products on $1.5 \%$ agarose gel and visualizing using UV trans-illuminator (Gel-Doc system).

\subsection{Sequencing and phylogenetic analysis}

The extraction of DNA from the positive sample clones was carried out using DNeasy Blood \& Tissue Kit (QIAGEN). The samples were confirmed by MPCR and the specific PCR amplicons were subjected for purification using QIAquick Gel Extraction Kit (QIAGEN). The purified PCR products were sequenced (Eurofins, Bangalore, India) by Sanger sequencing method. Sequences were edited through MegAlign and EditSeq programme from DNA star and were submitted to GenBank database. A data set of partial $16 \mathrm{~S}$ rRNA gene sequences of different isolates of A. butzleri (Table 2) and A. skirrowii (Table 3) were retrieved from GenBank (http://www.ncbi.nlm.nih.gov/GenBank/) for phylogenetic reconstruction. Phylogenetic tree for the $16 \mathrm{~S}$ rRNA gene sequences were constructed in MEGA6 software (Tamura et al., 2013) using the maximum likelihood method model and the evolutionary distances were computed by Kimura 2-parameter with gamma distribution for A. butzleri sequences. For the phylogenetic relationship study of A. skirrowii, maximum likelihood tree was derived using Jukes-Cantor algorithm (Jukes \& Cantor, 1969). The phylogenetic distances between different sequences were calculated by using MegAlign programme.

\section{Results}

\subsection{Arcobacter detection}

Out of the 204 fresh vegetable samples, 28 samples (13.73\%) were found positive for Arcobacter species by mPCR with expected size amplification of 401 bp and 641 bp products, specific for Arcobacter butzleri and Arcobacter skirrowii,

Table 2 Arcobacter butzleri strains used in phylogenetic analysis

\begin{tabular}{|c|c|c|c|c|}
\hline SI no & NCBI & Strain & Source & Country \\
\hline 1. & KT188763.1 & VPH/V3/IVRI/2014 & Vegetable & India (Present study) \\
\hline 2. & KT188764 & VPH/V10/IVRI/2014 & Vegetable & India (Present study) \\
\hline 3. & KT188765 & VPH/V36/IVRI/2014 & Vegetable & India (Present study) \\
\hline 4. & KT188766 & VPH/V92/IVRI/2014 & Vegetable & India (Present study) \\
\hline 5. & KT188767 & VPH/V124/IVRI/2014 & Vegetable & India(Present study) \\
\hline 6. & KT188768 & VPH/ 143/IVRI/2014 & Vegetable & India (Present study) \\
\hline 7. & KJ851584 & VPH/PS35/IVRI/2012) & Poultry skin & Bareilly (India) \\
\hline 8. & KC520497 & VPH/CM79/IVRI/2012 & Chicken meat & Bareilly (India) \\
\hline 9. & KJ364500.1 & MC1B6 & Raw milk & Gujarat (India) \\
\hline 10. & KT379981 & MAT6 & Fish & Mumbai (India) \\
\hline 11. & KF690259.1 & ANDL04 & Water & Odisha (India) \\
\hline 12. & JQ743025 & Arco-ka & Reptile & China \\
\hline 13. & KC551771 & AF1429 & Female pig & Canada \\
\hline 14. & LC094565 & GENT4 & River water & Japan \\
\hline 15. & HQ454094 & $78 \mathrm{e}$ & Tooth plaque of canine & The United States \\
\hline
\end{tabular}

Journal of Experimental Biology and Agriculture Science http://www.jebas.org 
Table 3 Arcobacter skirrowii strains used in phylogenetic analysis

\begin{tabular}{|ccccc|}
\hline SI no & NCBI & Strain & Source & Country \\
\hline 1. & KT188769 & VPH/V8/IVRI/2014 & Vegetable & India (Present study) \\
\hline 2. & KT188770 & VPH/V62/IVRI/2014 & Vegetable & India (Present study) \\
\hline 3. & KT188771 & VPH/V129/2014 & Vegetable & India (Present study) \\
\hline 4. & KC520496 & VPH/CM1/IVRI/2012 & Chicken meat & Bareilly (India) \\
\hline 5. & KF990326 & ASKBB/3 & Buffalo meat & Spainat (India) \\
\hline 6. & GU300769 & Houf 989 & Cow faeces & France \\
\hline 7. & DQ464344 & $449 / 80$ & Human stool & \\
\hline
\end{tabular}

respectively (Figure 1). Out of 28 positive samples, 23 samples were positive for A. butzleri, 5 showed mixed infections of $A$. butzleri and A. skirrowii. Of the note all the samples were found negative for A. cryaerophilus (Table 1). Out of 48 fresh carrot samples, 14 were positive for Arcobacter spp. and 11 of which were positive for A. butzleri and three revealed mixed infections of A. butzleri and A. skirrowii with prevalence rate of $29.17 \%$. Out of 46 fresh beet root samples, $10(21.74 \%)$ were detected positive for Arcobacter spp., of which 8 were positive for $A$. butzleri and 2 showed mixed infection of the two Arcobacter spp. Out of 38 fresh cabbage samples, 4 (10.53\%) samples were positive for A. butzleri. The samples from tomato (29), coriander (21) and cucumber (22) were found negative for Arcobacter spp. tested (Table 1). Cultural isolation of samples showed 6 Arcobacter positive colonies from carrot, which were further confirmed by both the biochemical tests (indoxyl acetate hydrolysis test and nitrate reduction test) and mPCR assay, 3 samples were positive for A. butzleri and 3 for A. skirrowii.

\subsection{Phylogenetic analysis}

The phyloanalysis using the maximum likelihood method for $A$. butzleri sequences showed that all the six A. butzleri isolates of the current study were clustering together with other Indian isolates forming a distinct clade (Figure 2). However, the low bootstrap values indicate that the Indian isolates are not diverse from the isolates of other parts of the world. Indian isolates were found more phylogenetically related with Chinese sequence from reptiles (JQ743025 strain Arco-ka). Also, no significant diversity between A. butzleri isolates of vegetable, environmental or animal origin was observed. Similarly, the maximum likely hood tree obtained using the Jukes-Cantor method for A. skirrowii sequences did not reveal any significant diversity according to the geographical location or the source of isolation (Figure 3). Analysis of phylogenetic distance by MegAlign programme showed 94.9 to $100 \%$ identity between A. butzleri isolates and 99.2 - $100 \%$ between $A$. skirrowii isolates.

KT 188771 A. skirrowi VPHN129/2014 KT188769 A. skirrowi VPHN8/VRI/2014

KT188770 A. skirrowil VPHN62IVR/2014 GU300769 A. skirrowii Hoư 989 Cow feces Spain DQ464344 A. skirrowii 449/80 Human stool France KF990326 A. skirrowii ASKBB/3 Buffalo meat Gujarat (india) KC520496 A. skirrowii VPH/CM1/NR/2012 Chicken meat Bareilly (India)

Figure 1 Multiplex PCR detection of Arcobacter butzleri and Arcobacter skirrowii from vegetable samples in agarose gel electrophoresis Lane M: Molecular weight marker, 100 bp plus

Lane 1, 2: Arcobacter butzleri (401 bp)

Lane 3: Mixed infection of Arcobacter butzleri (401 bp) and Arcobacter skirrowii (641 bp) Lane 4: Negative control 


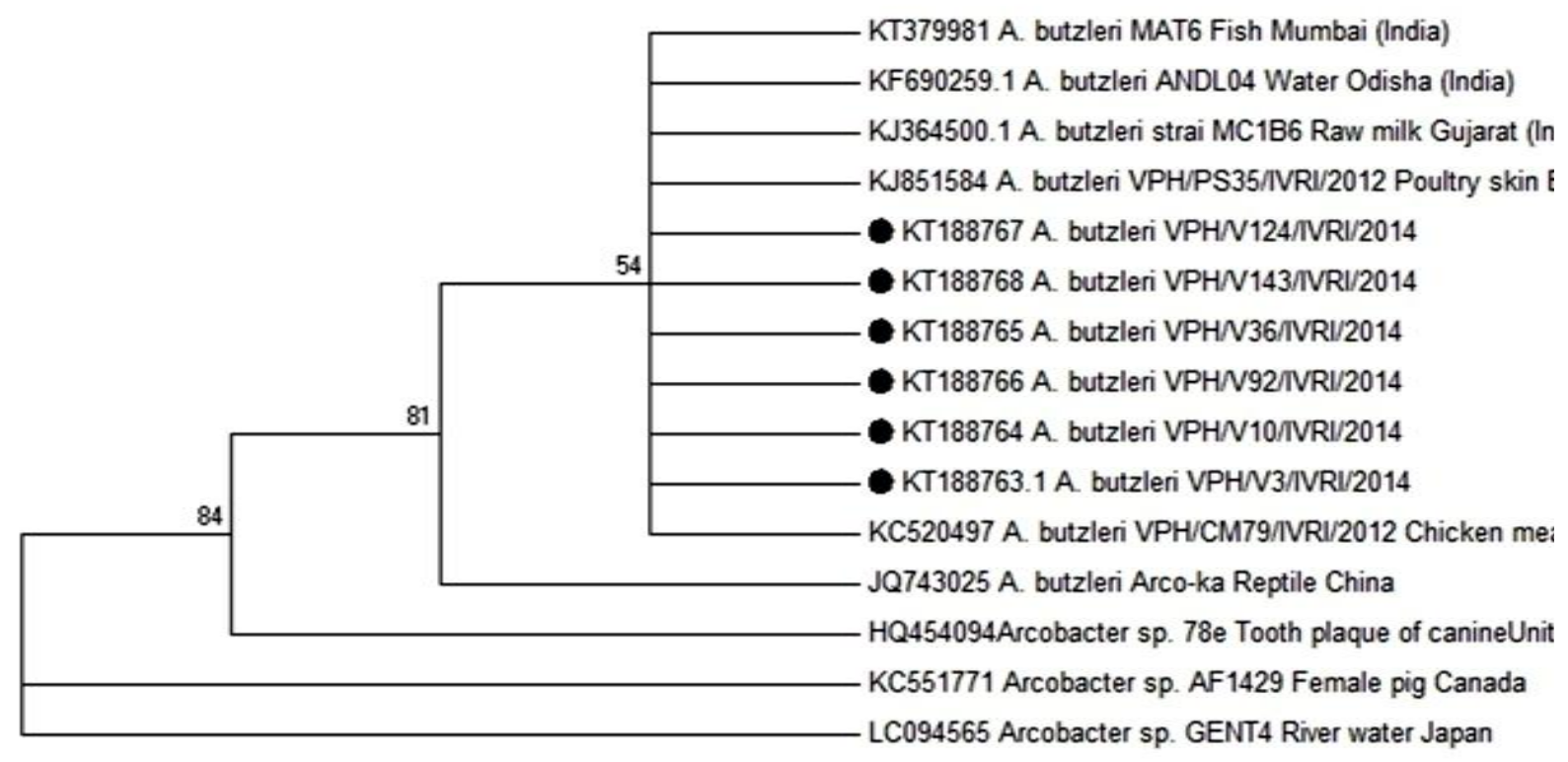

Figure 2 Phylogenetic tree of Arcobacter butzleri isolates. Phylogenetic relationship were inferred by MEGA6 software using the maximum likelihood method model and the evolutionary distances were computed by Kimura 2-parameter with gamma distribution for A. butzleri sequences. Isolate of present study are marked with black spot.

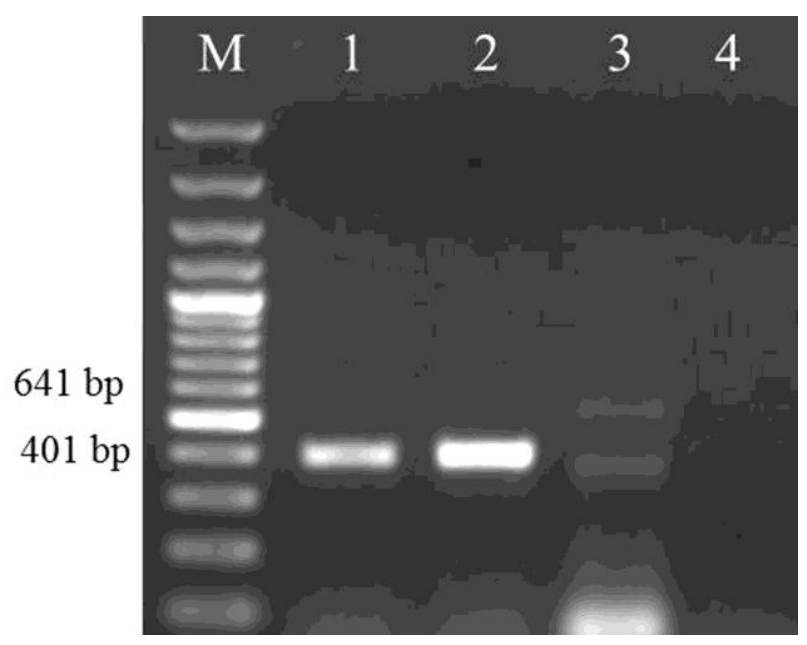

Figure 3 Phylogenetic tree of Arcobacter skirrowii isolates. Maximum likelihood tree was constructed using Jukes-Cantor algorithm. Isolate of present study are marked with black spot.

\section{Discussion}

The timely identification of the main source and cause of a disease outbreak helps in adopting measures to reduce the disease associated hazards in the future. Numerous disease incidences and outbreaks are reported in humans due to the ingestion of uncooked vegetables and fruits and their number has amplified in the recent years (Buck et al., 2003; Rahal et al., 2014). Major source of preharvest contamination of vegetables is irrigation water and post- harvest sources of bacterial contamination include human handling, harvesting equipment, transport containers, wild and domestic animals and transport vehicles (Burnett \& Beuchat, 2001).

Arcobacter is an important food-borne pathogen causing numerous outbreaks worldwide and cause diarrhoeal symptoms in humans and animals (Ramees et al., 2017). Arcobacters isolation has been successfully achieved from different food sources including meat (chicken meat, pork, beef, chevon, mutton and shellfish), meat products, water, milk, milk products, and vegetables (Winters \& Slavik, 2000; Rivas et al., 2004; Kabeya et al., 2004; Morita et al., 2004; Patyal et al., 2011; Ramees et al., 2014c; Ramees et al., 2014d). Hitherto reports confirm that meat serves as an important cause of human infections (Houf et al., 2003; Collado \& Figueras, 2011; Ramees et al., 2017).

In the present study, a prevalence rate of $13.73 \%$ for Arcobacters from raw vegetables was noted, which could be a potential source of infection from vegetables to humans. A. butzleri was the predominant species in vegetable samples followed by $A$. skirrowii. Reports regarding detection of Arcobacter spp. from vegetable sources are there from worldwide, and the present report establishes the finding of detecting Arcobacters from vegetable sources from India. Furthermore, we could detect $A$. skirrowii from a vegetable source, which has not been shown to be found in vegetable sources. Arcobacter spp. have been detected from vegetables (broccoli, carrot, celery, cauliflower, cantaloupe, lettuce, mushrooms, and tomato) and fruits (apple, grapes, kiwi, 
pine apple, strawberries, and watermelon) (Winters \& Slavik, 2000). Arcobacter spp. was identified in $20 \%$ of the samples from fresh lettuces by real-time PCR where A. butzleri predominated (Gonzalez \& Ferrus, 2011). Similarly, Campylobacter has been isolated from India in vegetables where 56 samples of different vegetables were analysed and 2 samples (1spinach and 1 fenugreek) showed the presence of Campylobacter jejuni (Kumar et al., 2001). Cultural isolation of Arcobacter positive colonies and biochemical testing results also confirmed the presence of Arcobacters in vegetable samples.

All the six A. butzleri isolates in the current study were phylogenetically related to other Indian isolates irrespective of the source of isolation and revealed a common phylogenic origin. The 16S rRNA gene sequences are conservative in Arcobacter spp without major mutation. Nayak et al. (2014) studied 16S rRNA gene sequence analysis of $A$. butzleri and reported a high similarity between isolates with minimum divergence. Indian $A$. butzleri isolates were phylogenetically related with Chinese isolates (of non-food origin) indicating a geographical relationship between the isolates from neighbouring countries without any significance with reference to source. A. skirrowii sequences did not reveal any geographical diversity and were not grouped in a different clade. The sequence analysis of 16S rRNA from a wide number of undefined bacterial isolates from environment or clinical cases showed a significant genetic similarity between $A$. skirrowii (Drancourt et al., 2000). The Arcobacter species are genetically similar irrespective of source and countries of origin. These findings show that Arcobacters are stable organism without significant genetic modification/ mutation. There are limited studies on epidemiological aspect of Arcobacter spp., which calls for extensive epidemiological and explorative research to know the real magnitude and role of vegetables in acting as potential source of Arcobacters and spreading the infection / disease to humans and their companion animals.

\section{Conclusion}

The study confirms that a high frequency of contamination of vegetable sources with Arcobacter species. Arcobacters contamination was detected in carrot, beet root and cabbage that are the vegetables usually consumed fresh in salads. Hence, there may be a chance of Arcobacter infection to humans from vegetable sources consumed without proper cooking and getting infection from eating of raw vegetables. This is the first report regarding the detection of Arcobacters from vegetable sources from India, and detection of A. skirrowii also from a vegetable source. The sequence analysis showed a significant genetic similarity among isolates from India and abroad. To decipher more knowledge on the magnitude of prevalence of Arcobacters in vegetable sources, their role as source of infection to human population, and to design suitable preventive measures to counter this pathogen of public health importance, additional intensive epidemiological studies are warranted in near future, particularly in resource poor countries.

\section{Conflict of interest}

There is no conflict of interest among all or any of the authors and also with the funding agencies.

\section{Acknowledgements}

The authors are highly thankful to the authority ICAR-Indian Veterinary Research Institute, Izatnagar (India) for providing necessary facilities to carry out this research work.

\section{References}

Atabay HI, Aydin F, Houf K, Sahin M, Vandamme P (2002) The prevalance of Arcobacter spp on chicken carcasses sold in retail markets in Turkey, and identifcation of the isolates using SDSPAGE. International Journal of Food Microbiology 81: 21-28.

Berger CN, Sodha SV, Shaw RK, Griffin PM, Pink D, Hand P, Frankel G (2010) Fresh fruit and vegetables as vehicles for the transmission of human pathogens. Environmental Microbiology $12: 2385-2397$

Beuchat LR (1996) Pathogenic Microorganisms Associated with Fresh Produce. Journal of Food Protection 2: 204-216.

Buck JW, Walcott RR, Beuchat LR (2003) Recent trends in microbiological safety of fruits and vegetables. Online Plant Health Progress, doi:101094/PHP-2003-0121-01-RV.

Burnett SL, Beuchat LR (2001) Human pathogens associated with raw produce and unpasteurized juices and difficulties in contamination. Journal of Industrial Microbiology \& Niotechnology 27: 104-110.

Collado L, Figueras MJ (2011) Taxonomy, epidemiology, and clinical relevance of the genus Arcobacter. Clinical Microbiology Rev 24: 174-192.

Dhama K, Rajagunalan S, Chakraborty S, Verma AK, Kumar A, Tiwari R, Kapoor S (2013) Food-borne pathogens of animal origin-diagnosis, prevention, control and their zoonotic significance: a review. Pakistan Journal of Biological Sciences 16: 1076-1085.

Drancourt M, Bollet C, Carlioz A, Martelin R, Gayral JP, Raoult D (2000) 16S ribosomal DNA sequence analysis of a large collection of environmental and clinical unidentifiable bacterial isolates. Journal of Clinical Microbiology 38 : 3623-3630. 
Ferreira S, Queiroz JA, Oleastro M, Domingues FC (2015) Insights in the pathogenesis and resistance of Arcobacter- A review. Critical Reviews in Microbiology Mar 25:1-20 [Epub ahead of print].

Franz E, van Bruggen AH (2008) Ecology of E coli O157: H7 and Salmonella enterica in the primary vegetable production chain. Critical Reviews in Microbiology 34: 143-161.

Gilbert MJ, Kik M, Timmerman AJ, Severs TT, Kusters JG, Duim B, Wagenaar JA (2014) Occurrence, Diversity, and Host Association of Intestinal Campylobacter, Arcobacter, and Helicobacter in Reptiles. PloS One 9: e101599.

Gonzalez AM, Ferrus MA (2011) Study of Arcobacter spp contamination in fresh lettuces detected by different cultural and molecular methods. International Journal of Food Microbiology 145: 311-314.

Gonzalez I, Garcia T, Antonlin A, Hernandez PE, Martin R (2000) Development of a combined PCR-culture technique Epidemiology and Infection for the rapid detection of Arcobacter spp in chicken meat. Letters in Applied Microbiology 30: 207212.

Greene SK, Daly ER, Talbot EA, Demma LJ, Holzbauer S, Patel NJ, Hill TA, Walderhaug MO, Hoekstra RM, Lynch MF and Painter JA (2008) Recurrent multistate outbreak of Salmonella Newport associated with tomatoes from contaminated fields, 2005. Epidemiology \& Infection $136: 157-165$.

Hausdorf L, Fröhling A, Schlüter O, Klocke M (2011) Analysis of the bacterial community within carrot wash water. Canadian Journal of Microbiology 57 : 447-452.

Houf K, De Zutter L, Van Hoof J, Vandamme P (2002) Assessment of the genetic diversity among arcobacters Isolated from poultry products by using two PCR-based typing methods. Applied and Environmental Microbiology 68: 2172-2178.

Houf K, De Zutter L, Van Hoof J, Vandamme P (2003) Molecular characterization of Arcobacter isolates collected in a poultry slaughter house. Journal of Food Protection 66: 364-369.

Houf K, Tutenel A, De Zutter L, Van Hoof J, Vandamme P (2000) Development of a multiplex PCR assay for the simultaneous detection and identification of Arcobacter butzleri, Arcobacter cryaerophilus and Arcobacter skirrowii. FEMS Immunology and Medical Microbiology 49: 337-45.

Hume ME, Harvey RB, Stanker LH, Droleskey RE, Poole TL, Zhang HB (2001) Genotypic variation among Arcobacter isolates from a farrow-to-finish swine facility. Journal of Food Protection 64 : 645-651.

Jacob J, Woodward D, Feuerpfeil I, Johnson WM (1998) Isolation of Arcobacter butzleri in raw water and drinking water treatment plants in Germany. Zentbl Hyg Umweltmed 201: 189198.

Jukes TH, Cantor CR (1969) Evolution of Protein Molecules In: Munro HN (Ed) Mammalian Protein Metabolism, Academic Press, New York, Pp: 21-132.

Kabeya H, Maruyama S, Morita Y, Ohsuga T, Ozawa S, Kobayashi Y, Abe M, Katsube Y, Mikami T (2004) Prevalence of Arcobacter species in retail meats and antimicrobial susceptibility of the isolates in Japan. International Journal of Food Microbiology 90: 303-308.

Karenlampi RI, Tolvanen TP, Hänninen ML (2004) Phylogenetic analysis and PCR restriction fragment length polymorphism identification of Campylobacter species based on partial groEL gene sequences. Journal of Clinical Microbiology 42: 5731-5738.

Kumar A, Agarwal RK, Bhilegaonkar KN, Shome BR, Bachhil VN (2001) Occurrence of Campylobacter jejuni in vegetables. International Journal of Food Microbiology 67: 153-155.

Lee MH, Choi C (2013) Survival of Arcobacter butzleri in Apple and Pear Purees. Journal of Food Safety 33: 333-339.

Morita Y, Maruyama S, Kabeya H, Boonmar S, Nimsuphan B, Nagai A, Kozawa K, Nakajima T, Mikami T, Kimura H (2004) Isolation and phylogenetic analysis of Arcobacter spp in ground chicken meat and environmental water in Japan and Thailand. Microbiology and Immunology 48 : 527-533.

Nayak AK, Wilson DL, Linz J, Rose JB, Mohanty PK (2014) DNA Sequence Analysis of gyrA provides a Rapid and Specific Assay to Identify Arcobacter butzleri Isolates from the Environment. International Journal of Current Microbiology and Applied Sciences $3: 512-529$.

Neubauer J, Jauk V, Szolgyenyi W (2003) Phenotypic and genotypic differentiation of Campylobacter spp isolated from Austrian broiler farms: a comparison. Avian Pathology 32: 33-37.

On SL, Harrington CS, Atabay HI (2003) Differentiation of Arcobacter species by numerical analysis of AFLP profiles and description of a novel Arcobacter from pig abortions and turkey faeces. Journal of Applied Microbiology 95: 1096-1105.

Park S, Szonyi B, Gautam R, Nightingale K, Anciso J, Ivanek R (2012) Risk factors for microbial contamination in fruits and 
vegetables at the preharvest level: a systematic review. Journal of Food Protection 75: 2055-2081.

Patyal A, Rathore RS, Mohan HV, Dhama K, Kumar A (2011) Prevalence of Arcobacter spp in humans, animals and foods of animal origin including sea food from India. Transboundary and Emerging Diseases 58: 402-410.

Rahal A, Mahima, Verma AK, Kumar A, Tiwari R, Kapoor S, Chakraborty S, Dhama K (2014). Phytonutrients and nutraceuticals in vegetables and their multi-dimensional medicinal and health benefits for humans and their companion animals: A review. Journal of Biological Sciences 14: 1-19.

Ramees TP, Dhama K, Karthik K, Rathore RS, Kumar A, Saminathan M, Tiwari R, Malik YS, Singh RK (2017) Arcobacter: an emerging food-borne zoonotic pathogen, its public health concerns and advances in diagnosis and control - a comprehensive review. Veterinary Quarterly 37: 136-161.

Ramees TP, Rathore RS, Bagalakote PS, Mohan HV, Kumar A, Dhama K (2014b) Detection of Arcobacter butzleri and Arcobacter cryaerophilus in clinical samples of humans and foods of animal origin by cultural and multiplex PCR based methods. Asian Journal of Animal and Veterinary Advances 9: 243-252.

Ramees TP, Rathore RS, Bagalakote PS, Mohan HV, Kumar A, Dhama K (2014a) Multiplex PCR Detection of Arcobacter butzleri and Arcobacter cryaerophilus in Skin of Poultry. Journal of Pure and Applied Microbiology 8: 1755-1758.
Ramees TP, Rathore RS, Bagalkot PS, Blessa Sailo, Mohan HV, Kumar, A Dhama, K, Singh RK (2014d) Genotyping and genetic diversity of Arcobacter butzleri and Arcobacter cryaerophilus isolated from different sources by using ERIC-PCR from India. Veterinary Quarterly 34: 211-217.

Ramees TP, Rathore RS, Bagalkot PS, Ravi Kumar GVPPS, Mohan HV, Anoopraj R, Kumar A, Dhama K (2014c) Real-time PCR detection of Arcobacter butzleri and Arcobacter cryaerophilus in chicken meat samples. Journal of Pure and Applied Microbiology 8 : 3165-3169.

Rice EW, Rodgers MR, Wesley IV, Johnson CH, Tanner SA (1999) Isolation of Arcobacter butzleri from ground water. Letters in Applied Microbiology 28: 31-35.

Rivas L, Fegan N, Vanderlinde P (2004) Isolation and characterization of Arcobacter butzleri from meat. International Journal of Food Microbiology 91: 31-41.

Tamura K, Stecher G, Peterson D, Filipski A, Kumar S (2013) MEGA6: Molecular evolutionary genetics analysis version 60 . Molecular Biology and Evolution 30: 2725-2729.

Wilson K (1987) Preparation of genomic DNA from bacteria. In: Ausubel FM, Brent R, Kingston RE, Moore DD, Smith JA, Seidman JG, Struhl K (Eds.), Current protocols in molecular biology John Wiley \& Sons, New York, NY, Pp 241.

Winters DK, Slavik MF (2000) Multiplex PCR detection of Campylobacter jejuni and Arcobacter butzleri in food products. Molecular and Cellular Probe 14: 95-99. 